\title{
Infectious-mononucleosis-like syndrome following haemodialysis for carbon tetrachloride poisoning
}

\author{
A. T. Proudfoot \\ B.Sc., M.B., Ch.B., M.R.C.P.E. \\ R. H. MACDONALD \\ M.B., Ch.B., D.Obst. R.C.O.G. \\ Senior House Officer \\ Registrar \\ Poisoning Treatment Centre, Royal Infirmary, Edinburgh
}

\begin{abstract}
Summary
A patient with renal failure after carbon tetrachloride poisoning is presented. Haemodialysis was required and renal function recovered completely. Convalescence was complicated by the development of an infectious-mononucleosis-like syndrome. The aetiology of this condition is discussed. The present case is the first to be reported after haemodialysis and transfusion of blood stored for at least 2 days.
\end{abstract}

\section{Introduction}

A syndrome of fever with atypical lymphocytes in the peripheral blood resembling those seen in infectious mononucleosis was first described in patients having had thoracoplasties and pulmonary resections for tuberculosis (Bergström \& Dahlström, 1957). It is a fairly common complication of open heart surgery (Smith, 1964; Bastin, Lapresle \& Dufrène, 1964a; Kääriäinen, Klemola \& Paloheimo, 1966).

The aetiology of this illness is obscure but its occurrence in single cases following blood-vessel grafting (Göthman \& Ohlsson, 1959), transfusion for bleeding duodenal ulceration (Tanaka, 1964), exchange transfusion (Bastin, Lapresle \& Dufrène 1964b), and after hysterectomy (Kääriäinen et al., 1966) supports the suggestion that it is due to some agent transmitted by blood transfusion as this is the only factor common to all cases. It seems probable that fresh blood was transfused at some stage in all these patients.

We wish to present a case following transfusion with only stored blood.

\section{Case report}

A 44-year-old chronic alcoholic was admitted to the Poisoning Treatment Centre on 16 October 1966. For the previous 10 days he had been drinking considerable quantities of cheap wine and a few hours before had been drinking methylated spirits. When denied more methylated spirits by the chemist he asked for something to remove a stain from his clothes and was sold a small bottle bearing only a brand name containing $30 \mathrm{ml}$ of what transpired to be $100 \%$ carbon tetracholoride. Thinking it contained alcohol he swallowed it. He gave a past history of malaria.

On admission $3 \mathrm{hr}$ later he was conscious and co-operative. His breath smelled of carbon tetrachloride. There was epigastric and right hypochondrial pain, tenderness and guarding. The liver edge was palpable two fingers' breadth below the right costal margin and was tender. The pulse rate was $98 / \mathrm{min}$ regular and the blood pressure $110 / 60 \mathrm{mmHg}$.

Peritoneal dialysis was started immediately in the hope of removing some of the poison and he was given hydrocortisone in an attempt to minimize hepatic damage. Over the next $48 \mathrm{hr}$ he developed severe oliguria and the blood urea and serum potassium rose. The patient was confused and disorientated making it difficult to manage his renal failure by peritoneal dialysis. He was therefore transferred to the Renal Isolation Unit, under the care of Dr J. S. Robson, where a Teflon-silastic shunt was inserted and haemodialysis on a Kolff twin-coil machine carried out on six occasions over the next 11 days. On each occasion the machine was primed with $1000 \mathrm{ml}$ stored blood. Over this time he was severely jaundiced, the serum bilirubin reaching a peak of $11.4 \mathrm{mg} / 100 \mathrm{ml}$. Two days after the last dialysis he entered the diuretic phase and his blood urea, serum potassium, creatinine clearance and liver function tests reverted slowly to normal.

He was about to be discharged when he developed an intermittent pyrexia on 25 November 1966. The temperature rose daily to about $101^{\circ} \mathrm{F}$. Despite this he remained mobile and generally well with minimal muscle pains, pain behind the eyes, and sweating at the height of the fever. 
There was very slight epigastric tenderness but on repeated examination no rash, lymphadenopathy, splenomegaly or arthritis. The chest X-ray, Paul-Bunnell, Widal and abortus agglutination tests, Mantoux 1:1000, stool cultures and blood films for malarial parasites were all negative. A slightly elevated ASO titre of 600 Todd units was found. The diaphragms were screened but moved normally. The white cell count was $8300 /$ $\mathrm{mm}^{3}$ and the cells normal.

Transient purpura appeared on both legs, particularly round the ankles, on 3 December 1966. Hess' test was negative. The white cell count was now $9500 / \mathrm{mm}^{3}$ with $40 \%$ lymphocytes many of which were atypical and the platelet count $140,000 / \mathrm{mm}^{3}$. The total white cell count rose to a peak of 19,700 on the 18th day of fever when only $21 \%$ of the cells were neutrophils ; monocytes comprised $9 \%$ and lymphocytes $68 \%$ many of which were atypical.

Throughout the 4 weeks' febrile illness he remained disproportionately well and without treatment the temperature returned to normal on 21 December 1966 . The total white cell count and the percentage of lymphocytes fell slowly though a few atypical cells were still present early in January. The Paul-Bunnell test was negative on five occasions over the febrile period. The toxoplasma dye test on blood taken at the end of the illness was positive at $1: 32$.

\section{Discussion}

This man's carbon tetrachloride poisoning followed a typical clinical course. Peritoneal dialysis has been used before to treat the subsequent renal failure (Hager \& Merrill, 1963) but there is only one previous report of it having been used for the purpose of attempting to remove the poison. No estimate was made of the amount removed by dialysis (Maher \& Schreiner, 1967). In our case carbon tetrachloride was found in the gastric aspirate, lavage fluid and subsequent samples of vomitus at concentrations of $0.4 \mathrm{mg} /$ $100 \mathrm{ml}$, in the small amount of urine passed $(0.2 \mathrm{mg} / 100 \mathrm{ml})$ and in specimens of peritoneal dialysate $(0 \cdot 1 \mathrm{mg} / 100 \mathrm{ml})$. From these figures it would seern unlikely that this minimal recovery of carbon tetrachloride by peritoneal dialysis reduced the ultimate renal and hepatic damage.

The febrile illness in this patient, starting about 4 weeks after haemodialysis with its benign, selflimiting course over 4 weeks and peripheral blood picture suggestive of glandular fever is typical of what has come to be known as the infectious-mononucleosis-like syndrome.

The present case is probably the first to be reported after haemodialysis. The clinical fea- tures resemble those previously recorded. The absence of splenomegaly and lymphadenopathy is not unusual but purpura has not been previously described though four cases reported by Smith (1964) had transient maculo-papular rashes At the time the purpura was present Hess' test was negative and the platelet count was 140,000 / $\mathrm{mm}^{3}$. It is therefore unlikely that the purpura was due to thrombocytopenia. The Paul-Bunnell test was consistently negative and though the toxoplasma dye test was positive it is estimated that $40 \%$ of adults will have titres of this value; its significance is therefore doubtful. The peak total white cell count 18 days after the onset of fever is probably the highest yet recorded in this syndrome, most cases having normal or only slightly elevated counts. The high incidence of the infectious-mononucleosis-like syndrome after open heart surgery-up to $11 \%$ in one series (Wheeler, Turner \& Scannel, 1962) - suggested that relatively large quantities of blood must be transfused. In this respect the present case is similar.

Kääriäinen et al. (1966) state that no case has been reported with certainty after transfusion of refrigerated blood though later Horton (1966) presented two cases in which blood stored for $24 \mathrm{hr}$ had been followed by the typical illness. In our case the citrated blood had been stored between 2 and 9 days, eleven donors being in volved. The administration of corticosteroids, as in this patient, may predispose to the development of the infectious-mononucleosis-like syndrome.

Kääriäinen and his colleagues (1966) have demonstrated a significant rise in complement fixing antibodies to cytomegalovirus over the course of the illness in four patients and suggest that this virus transmitted by blood may be the cause of the syndrome.

\section{Acknowledgments}

We are grateful to Dr Henry Matthew, Consultant-inCharge, Poisoning Treatment Centre, Edinburgh Royal Infirmary, for his permission and encouragement to publish this case and to Dr S. L. Tompsett, Reader in Clinical Chemistry, University of Edinburgh, who estimated the carbon tetrachloride content of the fluids.

\section{References}

Bastin, R., Lapresle, C. \& Dufrène, F. (1964a) Syndrome mononucléosique après interventions chirugicales ou pulmonaires. Bull. Mem. Soc. med. Hop., Paris, 115, 1183.

Bastin, R., Lapresle, C. \& Dufrène, F. (1964b) Syndrome mononucléosique après exsanguino-transfusion. Bull. Mem. Soc. med. Hop., Paris, 115, 1195.

Bergström, I. \& DAHLSTRöm, G. (1957) Fever with a blood picture resembling infectious mononucleosis in operated tuberculosis cases. Acta tuberc. scand. 34, 132. 
Göthman, B. \& OHLsson, W.T.L. (1959) Fever with haematologic changes resembling infectious mononucleosis as a sequel of blood vessel grafting. Angiology, 10, 355.

Hager, E.B. \& Merrill, J.P. (1963) Peritoneal dialysis and acute renal failure. Surg. Clin. N. Amer. 43, 883.

Horton, E.H. (1966) Infectious mononucleosis-like syndrome after transfusion. Brit. med. J. i, 1419.

KäÄriänen, L., Klemola, E. \& Paloheimo, J. (1966) Rise of cytomegalovirus antibodies in an infectious mononucleosis-like syndrome after transfusion. Brit. med. J. i, 1270.
MAHER, J.F. \& SChreiner, G.E. (1967) The dialysis of poisons and drugs. Trans. Amer. Soc. artif. intern. Organs, 13, 369.

Smith, D.E. (1964) A syndrome resembling infectious mononucleosis after open heart surgery. Brit. med. J. i, 945.

TANAKA, K.R. (1964) Infectious mononucleosis syndromes. Brit. med. J. ii, 122.

Wheeler, E.O., Turner, J.D. \& Scannel, J.G. (1962) Fever, splenomegaly and atypical lymphocytes. A syndrome observed after cardiac surgery utilizing a pump oxygenator. New Engl. J. Med. 266, 454.

\section{Endocarditis parietalis fibroplastica (Loffler's disease)}

\author{
R. C. JenNings \\ M.D.(Lond.), L.M.S.S.A., M.C.Path., Dip.Path. \\ Consultant Pathologist
}

\author{
C. D. R. Pengelly \\ M.D.(Brist.), M.R.C.P., M.R.C.P.E. \\ Consultant Physician
}

North and Mid-Cheshire Hospitals

\section{Summary}

A case of endocarditis parietalis fibroplastica (Löffler's disease) is described and the aetiology and pathogenesis briefly discussed. Some of the relevant literature is reviewed.

\section{Introduction}

Endocarditis parietalis fibroplastica is a rare fatal disease of unknown aetiology in which there is a progressive subendocardial mural fibrosis. It is associated with a peripheral blood eosinophilia sometimes of leukaemoid proportions.

\section{Case report}

J.W., a gas fitter aged 20, was admitted for investigation to the Grange Hospital, Weaverham, on 27 April 1966 with a history of cough, morning wheezing and a little green sputum for 6 months. He complained of breathlessness on exertion and had lost 2 stones in weight and had occasional vomiting. He had never been abroad.

On examination he was pale and had a lowgrade pyrexia. There were poor basal breath sounds in the chest and scanty rales. His heart was slightly enlarged with a soft apical systolic murmur. Blood pressure was $160 / 110 \mathrm{mmHg}$. The spleen and liver were both palpable about $\frac{1}{2}$ in. below the costal margin. Urine contained albumin ++ and a trace of sugar.

\section{Investigations}

X-ray chest: bilateral small.pleural effusions and some diffuse shadows in both lungs. Vital capacity 2.34 litres (predicted from height and weight: 4.92 litres). FEV $_{1} 74 \%$, not improved by isoprenaline inhalation. ECG showed flattening of $\mathrm{T}$ waves in leads III, aVF and $\mathrm{V} 4,5$ and $6 . \mathrm{Hb}, 8.6 \mathrm{~g} / 100 \mathrm{ml}$; PCV, 32\%, MCHC, $27 \%$; ESR $33 \mathrm{~mm}$ in the 1st hour (Wintrobe); WBC, $35,000 / \mathrm{mm}^{3}$ (neutrophils $20 \%$, lymphocytes $9 \%$, monocytes $3 \%$, eosinophils $68 \%$ ) ; platelets $184,000 / \mathrm{mm}^{3}$; direct Coombs' test negative; leucocyte alkaline phosphatase: low score. Sternal marrow; normal cellularity; normoblastic erythropoiesis with a marked increase of eosinophils and their precursors. The appearances were those of an eosinophilic hyperplasia. LE cells not found, Rose-Waaler test negative, blood sugar $80 \mathrm{mg} / 100 \mathrm{ml}$, serum electrolytes and liver function tests normal. Serum proteins: albumin $4.5 \mathrm{~g} / 100 \mathrm{ml}$; globulin $3.0 \mathrm{~g} / 100 \mathrm{ml}$; electrophoresis: slight increase in $\gamma$-globulin. Stools for occult blood (four tests) positive. Sputum culture: normal flora. Urine deposit: red cells ++ , leucocytes + . Two blood cultures sterile. Mantoux test $1 / 1000$ positive. Precipitin test for trichinosis negative. Needle biopsy of the liver showed scattered eosinophils throughout the parenchyma with larger groups of similar cells mainly in the portal tracts.

A provisional diagnosis of polyarteritis nodosa was made and oral treatment with prednisolone $10 \mathrm{mg}$ t.d.s. was started: this was gradually reduced to $7.5 \mathrm{mg}$ t.d.s. and a course of erythromycin was given. He improved a little, his breathlessness lessened and he was discharged from hospital on 23 May 1966. Late in June he developed further cardiac enlargement and a protodiastolic gallop at the apex; his spleen and liver were both palpable 2 in. below the costal 